\title{
Antibacterial Activity of Ethanolic Extract and Infusion of Bauhinia variegata Leaves Against Streptococcus pyogenes
}

\section{Pengujian Aktivitas Antibakteri Ekstrak Etanol dan Infusa Daun Kupu-Kupu (Bauhinia variegata) Terhadap Bakteri Streptococcus pyogenes}

\author{
Istiqamatush Sholihah* and Ika Trisharyanti D.K. \\ Pharmacy faculty, University of Muhammadiyah Surakarta \\ Jl A. Yani Tromol Pos I, Pabelan Kartasura Surakarta 57102 \\ *e-mail: istiyaisti@yahoo.co.id
}

\begin{abstract}
Bauhinia variegata is a plant that has many benefits and widely grown in Indonesia. However, the utilization is still limited as the shade and ornamental plant. The purpose of this study was to determine the antibacterial ethanol extract activity and the infusion of B. variegata leaves toward Streptococcus pyogenes and to determine the classes of compounds that have antibacterial activity. $B$. variegata leaves were extracted by maceration and infusion with $96 \%$ ethanol and distilled water. The test method of antibacterial activity was using disc difussion Kirby Bauer methods. The Analyses of the compounds contained in the B. variegata leaves were done by TLC (Thin Layer Chromatography) and phytochemical tests. The results showed that ethanol extract and infusion of $B$. variegata leaves did not have antibacterial activity toward Streptococcus pyogenes. TLC results and phytochemical testss showed that the ethanol extract of B. variegata leaves contained tannins, saponins, terpenoids, and alkaloids. Moreover, the infusion of B. variegata leaves comprised of saponins and alkaloids.
\end{abstract}

Keywords: Bauhinia variegata, antibacterial, Streptococcus pyogenes, maceration, infussion.

\begin{abstract}
Abstrak
Tanaman kupu-kupu (Bauhinia variegata) merupakan tanaman yang mempunyai berbagai khasiat dan banyak ditanam di Indonesia. Daun kupu-kupu digunakan oleh masyarakat Sumba Barat Nusa Tenggara Timur sebagai obat bisul. Tujuan penelitian ini yaitu untuk mengetahui aktivitas antibakteri ekstrak etanol dan infusa daun kupu-kupu terhadapStreptococcus pyogenes dan mengetahui golongan senyawa yang mempunyai aktivitas antibakteri. Daun kupu-kupu diekstraksi dengan cara maserasi dan infundasi dengan pelarut etanol 96\% dan akuades. Metode uji aktivitas antibakteri digunakan metode disc difusson Kirby Bauer. Analisis golongan senyawa yang terdapat dalam daun kupu-kupu dilakukan dengan cara Kromatografi Lapis Tipis (KLT) dan uji tabung. Hasil penelitian menunjukkanbahwa ekstrak etanol dan infusa daun kupu-kupu tidak mempunyai aktivitas antibakteri terhadap bakteri Streptococcus pyogenes. Hasil KLT dan uji tabung menunjukkan bahwa ekstrak etanol daun kupu-kupu mengandung tanin, saponin, terpenoid, dan alkaloid. Sedangkan infusa daun kupu-kupu terdapat saponin dan alkaloid.
\end{abstract}

Kata kunci: Bauhinia variegata, antibakteri, Streptococcus pyogenes, maserasi, infundasi.

\section{Introduction}

Infection is an entry condition of microorganisms into the body tissues which proliferate and cause disease (Hartati, 2012). One example of bacteria which cause the infection is Streptococcus pyogenes (Jawetz et al., 1991).

Streptococcus pyogenes is a large group of bacteria that can cause a local infection and systemic (Mardiastuti et al., 2007). The local infection that often occurs is pharyngitis. In children, pharyngitis may extend into the middle ear, mastoid, and the lining of the brain. If there occurs the most severe inflammation, it can damage the tissue and shape an abscess. Streptococcus pyogenes is a large group of bacteria that can cause a local infection and systemic (Mardiastuti et al., 2007). The local infection that often occurs is pharyngitis. 
Streptococcus pyogenes can infect various parts of the body such as the pharynx and the skin. The infection of pharynx can cause abscesses, whereas the infections of skin may cause impetigo (Jawetz et al., 1991). The firstline drug treatment of Streptococcus pyogenes infection is penicillin. But for this time the Streptococcus pyogenes has experienced resistance toward penicillin. The large number of resistance toward synthetic antibacterial drug makes the use of plants as a new antibiotic agent needs to be done. The excess of using plants as a medicine is the fewer side effects which they have as compared to the synthetic drugs (Joshi and Edington, 1990 in Joshi et al., 2009).

Bauhinia variegata is widely planted as an ornamental plant in Indonesia. The benefits of using $B$. variegata plant are not known by many people, except for the area of East Nusa Tenggara (NTT), which already use it as a medicine. Since a long time, the Indian State has been used $B$. variegata plant as the medicine (Dhale, 2011). So, the research needs to be done to ensure these properties.

The results of research which is conducted by Dhale (2011), ethanol is a solvent that can attract more the secondary metabolites compound of leaves or bark of $B$. variegata plants. The use of aqueous solvent is intended as a proof of use in society. The antibacterial activity was shown by the research of Mali et al., (2008), that the stems of B. variegata are capable to kill Staphylococcus aureus, Bacillus subtilis, Pseudomonas aeruginosa, Escherichia coli, Aspergillus niger, and Candida albicans, with the resulting inhibition zone toward Staphylococcus aureus is 20, 4 $\mathrm{mm}$ at a concentration of $20 \mathrm{mg} / \mathrm{mL}$. Dhale (2011) showed that the ethanol extract of leaves of B. Variegata the bacterium Staphylococcus aureus also showed antibacterial activity with the resulting inhibition zone $15 \mathrm{~mm}$ at a concentration of $20 \mathrm{mg} / \mathrm{mL}$.

\section{Materials and Methods}

\section{Material}

The tools which used in this research are oven (Memmert), autoclave (My Life), tools glass (Pyrex Iwaki), analytical balance (Precisa), Laminar Air Flow (Astari Niagara), rotary evaporator (Heidolph), microscope (Olympus), waterbath (Memmert), vortex (Thermolyne corporation), inkubation shaker (New Brunswick Scientific) UV $254 \mathrm{~nm}$ and $365 \mathrm{~nm}$ UV. The materials which used in this research are B. variegata leaves that is obtained from Surakarta, ethanol 96\% (mitra medika) and distilled water, the Streptococcus pyogenes bacteria, Muller-Hinton agar $(\mathrm{MH})$ (Oxoid), blood agar, brain heart infusion media (Oxoid), $0.9 \% \mathrm{NaCl}$ solution, A Gram paint, Gram B paint, C Gram paint, Gram D paint, Mc. Farland standards $\left(1,5 \times 10^{8} \mathrm{CFU} /\right.$ $\mathrm{mL})$, DMSO, hexane: ethyl acetate $(6: 4) \mathrm{v} / \mathrm{v}$, and the reagent spray $\mathrm{FeCl}_{3}$, Dragendrof, Liebermann-Burchard (LB).

The purpose of this study was to determine the antibacterial ethanol extract activity and the infusion of B. variegata leaves toward Streptococcus pyogenes and to determine the classes of compounds that have antibacterial activity.

\section{Research Methodology}

a. The Extraction of $\boldsymbol{B}$. variegata leaves

$B$. Variegata leaves took from the Surakarta area and then extracted by ethanol (96\%) maceration method and infusion with water. Maceration method by soaking the dried of B. variegata leaves with $7.5 \mathrm{~L} 96 \%$ ethanol. Infussion method was done by boiling $50 \mathrm{~g}$ of dried B. variegata leaves with $500 \mathrm{~mL}$ of distilled water.

\section{b. Microbiology Test}

\section{1) Preparation of bacterial suspension}

Streptococcus pyogenes bacteria colonies were taken with a sterile loop and then smeared on Muller-Hinton agar by streak plate method. Then, it was incubated for 24 hours at temperature of $37^{\circ} \mathrm{C}$. Proliferated bacteria stored at $4^{\circ} \mathrm{C}$ for use as a bacterial stock.

Bacteria were taken from stock culture (3-5 colonies) by using a sterile loop, then suspended in $5 \mathrm{~mL}$ BHI media, 
incubated at $37^{\circ} \mathrm{C}$ for 2-6 hours. The suspension was diluted with sterile saline until its turbidity was equal to Mc Farland standard $\left(1,5 \times 10^{8} \mathrm{CFU} / \mathrm{mL}\right)$.

\section{2) Biochemistry test}

Biochemical tests consisted of Gram Staining and hemolysis test by using blood agar.

\section{c. Antibacterial activity test}

Antibacterial activity test was performed using the disc diffusion method. MullerHinton agar was inoculated with Streptococcus pyogenes. Then the paper disk was filled with a series of $B$. variegata leaves extract. Negative control was DMSO and positive control was erythromycin. Concentration of $B$. variegata leaves extract consisted of $32 \%, 16 \%, 8 \%$ and $4 \%$, while the concentration of infusion series of $B$. variegata leaves were $8 \%, 4 \%, 2 \%$ and $1 \%$. Plate contained extract and control was incubated at $37^{\circ} \mathrm{C}$ for 24 hours and diameter of inhibitory zone was measured.

\section{d. TLC Test and Phytochemical Tests}

Ethanol extract was dissolved with ethanol. The solvent of ethanol extract as much as $3 \mathrm{uL}$ are spotted on GF 254 silica stationary phase and then eluted with the mobile phase optimization results. The mobile phase was hexane:ethyl acetate (6:4). Chromatogram results observed under $254 \mathrm{~nm}$ and $366 \mathrm{~nm}$ ultra violets light. The spots were detected by spray reagent $\mathrm{FeCl}_{3}$, Dragendrof, LB. Phytochemical tests were performed to detect alkaloids, saponins, tannins, terpenoids, and steroids.

\section{Results and Discussion}

\section{Extraction}

Maceration is an appropriate way to sum up the ingredients that have been refined. The solvents which used for soaking will seep and flex the cell structure of plant so the substances would easily dissolve and can be dissolved (Ansel, 1989). The infusion which is not hard ingredients is made with $10 \%$ bulbs
(Depkes RI, 1979). The concentrated ethanol extract obtained from $B$. variegata leaves was 34.62 grams. The result for one $B$. variegata leaves infusion was obtained approximately $450 \mathrm{~mL}$.

\section{Identification of Bacteria}

\section{a. Bacteria Staining}

Streptococcus pyogenes is a Grampositive bacteria group A which includes to the beta-hemolytic streptococcus (Jawetz et al., 1991). These bacteria shaped cocci with a typical chain (usually $\geq 8$ cocci). The cocci are formed slightly elongated in the direction of the axis of the chain (Syahrurachman et al., 1994). The color of gram-positive bacteria is purple after done the staining bacteria. The purple color is resulting because the Gram-positive bacteria can bind Gram A stain (crystal violet) (Capuccino \& Sherman, 2013). The bacterial staining result was spherical bacteria (cocci), purple, and the colony formed a chain.

\section{b. Biochemistry Test}

Identification of Streptococcus pyogenes was done by using blood agar. This detection was used to determine the ability of bacteria to lyse red blood cells. The results showed that colonies on the blood agar formed greenish-gray color colonies with a clear zone around it. Syahrurachman et al., (1994) said that Bacteria on blood agar that had been incubated for 18-24 hours will form grayish small colonies, round shape with a flat section verges and speck of fluid on the surface.

\section{Antibacterial Activity Test}

The aims of this analysis were to determine the antibacterial activity of $B$. variegata leaves with different extraction method. This test used Kirby Bauer disc diffusion method by using paper disks with a diameter of $6 \mathrm{~mm}$. The results was obtained by measuring the diameter of inhibition zone which was marked 
by a clear area around the paper disk that contained ethanol extract concentration series or the infusion of $B$. variegate leaves.

Antibacterial test results ethanol extract and infusion of $B$. variegata leaves are presented in Table 1. The differences of extract concentration in each disk were needed to determine the effect of concentration on the antibacterial activity. Generally, the higher of extract concentration, the greater inhibition zone is formed. However, the test results of antibacterial activity of ethanol extract and infusion of $B$. variegata leaves showed that there were almost no different activities among concentrations of extract and infusion toward Streptococcus pyogenes. The test results of ethanol extract antibacterial activity was formed $6.3 \mathrm{~mm}$ inhibition zone at a concentration of $4 \%$, while it was similar to the inhibition zone of $B$. variegata leaves infusion at a concentration of $2 \%$ and $1 \%$. This may be caused by not all of active leave compounds that play an active role toward antibacterial activity was not well extracted.

According to Rashid et al. (2014) ethanol extracts of $B$. variegata leaves showed the inhibition zone of $12 \mathrm{~mm}$ at a concentration of $32 \%$ and $13 \mathrm{~mm}$ at a concentration of $64 \%$ toward Streptococcus pyogenes. Another study also mentions that the ethanol extract of antibacterial activity of $B$. variegata leaves was better than the other solvents (Dhale, 2011).

Table 1. Test results of antibacterial activity of ethanol extract and infusion of $B$. variegata toward Streptococcus pyogenes

\begin{tabular}{lccc}
\hline \multicolumn{1}{c}{ Sample } & concentration & zone of inhibitor $(\mathbf{m m})$ & Remarks \\
\hline & $32 \%$ & 6 & - \\
Ethanol extract of $B$. & $16 \%$ & 6 & - \\
Variegata leaves & $8 \%$ & 6 & radical \\
& $4 \%$ & 6,33 & - \\
DMSO & $10 \mu \mathrm{L}$ & 6 & radical \\
Eritromisin & $15 \mu \mathrm{g}$ & 21,17 & - \\
& $8 \%$ & 6 & - \\
Infusion of $B$. & $4 \%$ & 6 & radical \\
variegata leaves & $2 \%$ & 6,33 & radical \\
& $1 \%$ & 6,33 & - \\
DMSO & $10 \mu \mathrm{L}$ & 6 & Radical \\
Eritromisin & $15 \mu \mathrm{g}$ & 21,33 & \\
\hline
\end{tabular}

The differences in the test results with the previous studies was caused by several factors, namely the chemical content and the different of where the plants grown. the sample of this study was taken from Surakarta, while the research of Dhale (2011) from India, and Rashid et al. (2014) from Iraq.

\section{TLC and Phytochemical Test}

Thin layer chromatography analysis is performed to determine the content of compounds which present in the ethanol extract of $B$. variegata leaves. The concentration used for the TLC test was $8 \%$ extract. The stationary phase was silica gel GF254, while mobile phase was hexane: ethyl acetate (6:4).

Alkaloid identification can be done by a spray reagent Dragendrof that will show some brown or orange spots (Wagner and Bladt, 1996). Alkaloid will cause a purple fluorescence in UV $366 \mathrm{~nm}$ before spraying. $\mathrm{FeCl}_{3}$ can be used to detect tannin, visual vision shows blue, blue-black, and black (Farnsworth, 1966). Flavonoid compound with a reagent spray sitoborat shows yellow, green, or blue in UV 366 nm (Wagner and Bladt, 1996).

The result of the ethanol extract of $B$. variegata leaves which used reagent Dragendrof showed brown spots on the hRf $39 \mathrm{~mm}$. It indicates that there were alkaloids in the $B$. 
variegata leaves. Other test result was done by using $\mathrm{FeCl}_{3}$ reagent was spot of green color on hRf $47 \mathrm{~mm}$. These spots indicate the presence of tannin. LB reagent was used to determine steroid with the color are blue, green, pink, brown, and yellow on visible light. Meanwhile, glycosides were colored gray to red brown in UV $366 \mathrm{~nm}$ (Wagner and Bladt, 1996). The test results with LB reagents showed gray spots in visible light and purple when exposed by UV 366. It showed that there were neither steroids nor glycosides in the extract.

Table 2. Results of KLT analysis of the ethanol extract of $B$. variegata leaves using the mobile phase hexane:ethyl acetate (6:4) and stationary phase silica gel GF $_{254}$

\begin{tabular}{|c|c|c|c|c|c|c|c|c|c|c|}
\hline \multirow[b]{2}{*}{ No } & \multirow[b]{2}{*}{$\begin{array}{c}\text { hRf } \\
\text { vis }\end{array}$} & \multicolumn{3}{|c|}{ Before sprying } & \multicolumn{4}{|c|}{ After spraying } & & \multirow[b]{2}{*}{ Compounds } \\
\hline & & $\begin{array}{l}\text { UV } \\
254 \\
\text { nm }\end{array}$ & $\begin{array}{l}\text { UV } \\
366 \\
\mathrm{~nm}\end{array}$ & LB vis & $\begin{array}{c}\text { LB UV } \\
366 \\
\text { nm }\end{array}$ & $\begin{array}{c}\mathrm{FeCl}_{3} \\
\text { vis }\end{array}$ & $\begin{array}{c}\text { Dra- } \\
\text { gen-drof } \\
\text { vis }\end{array}$ & $\begin{array}{c}\text { Dra- } \\
\text { gen- } \\
\text { drof- } \\
\mathrm{H}_{2} \mathrm{SO}_{4} \\
\text { vis }\end{array}$ & & \\
\hline 1 & 0 & $\mathrm{C}$ & $\mathrm{C}$ & A & A & $\mathrm{U}$ & $\mathrm{C}$ & $\mathrm{C}$ & $\mathrm{C}$ & - \\
\hline 2 & 8 & $\mathrm{H}$ & - & A & A & - & - & - & - & - \\
\hline 3 & 10 & $\mathrm{H}$ & - & A & A & - & - & - & - & - \\
\hline 4 & 19 & $\mathrm{~K}$ & - & A & - & & - & - & - & - \\
\hline 5 & 23 & $\mathrm{~K}$ & - & $\mathrm{H}$ & - & & - & - & - & - \\
\hline 6 & 27 & $\mathrm{H}$ & - & $\mathrm{H}$ & - & & - & - & - & - \\
\hline 7 & 34 & $\mathrm{~A}$ & - & A & A & $\mathrm{U}$ & $\mathrm{C}$ & $\mathrm{C}$ & $\mathrm{AH}$ & Alkaloid \\
\hline 8 & 36 & - & - & & - & & & & $\mathrm{A}$ & - \\
\hline 9 & 39 & $\mathrm{~A}$ & - & $\mathrm{H}$ & $\mathrm{A}$ & $\mathrm{U}$ & $\mathrm{C}$ & $\mathrm{H}$ & $\mathrm{C}$ & - \\
\hline 10 & 43 & $\mathrm{~A}$ & - & $\mathrm{H}$ & A & $\mathrm{U}$ & - & - & - & - \\
\hline 11 & 47 & - & - & - & $\mathrm{AC}$ & $\mathrm{U}$ & $\mathrm{H}$ & - & - & Tannins \\
\hline \multicolumn{11}{|c|}{ Remarks: } \\
\hline $\mathbf{L B}$ & \multicolumn{4}{|c|}{$=$ Libermann-Burchard } & & $\mathbf{U}$ & \multicolumn{2}{|l|}{$=$ purple } & & \\
\hline $\mathbf{C}$ & \multicolumn{4}{|c|}{$=$ brown } & & $\mathbf{H}$ & \multicolumn{2}{|c|}{$=$ green } & & \\
\hline $\mathbf{A}$ & \multicolumn{4}{|c|}{ = grey } & & AH & \multicolumn{2}{|c|}{ = grey-black } & & \\
\hline $\mathbf{K}$ & \multicolumn{4}{|c|}{$=$ yellow } & & $\mathbf{A C}$ & \multicolumn{2}{|c|}{$=$ grey-brownish } & & \\
\hline
\end{tabular}

Test compound classes of $B$. variegata leaves also done with the phytochemical test. The result of the ethanol extract of $B$. variegata leaves indicated the existence of saponin, visible presence of bubbles on the surface of the solvent. There was also the alkaloid compound that showed by sediment on the bottom of the tube. Terpenoids were also contained in the $B$. variegata, it showed that there was red color change in the solvent of the extract. The test results of infusion of butterfly leaf showed the existence of compound saponin, indicated by the existence of bubbles on the surface of the tube. There was also the alkaloid compounds that showed by the precipitate of a white small role in the solvent. Tannin test showed the change of solvent color into turbid green, this did not indicate the presence of tannin in the infusion of $B$. variegata leaves. Terpenoids and steroid compounds test also did not show positive results, it was shown by not formed blue color which indicates steroid and red color that shows terpenoids.

The ethanol extract which was taken from India was containing compounds of alkaloids, glycosides, phenolics, tannins, lignins and saponins (Dhale, 2011). Other studies explained that $B$. variegata leave contained secondary metabolites including anthraquinone, terpenoids, phenolics, flavonoids, saponins, tannins, alkaloids and cardiac gikosida (Mishra, 2013). B. variegata leaves taken from Baghdad, Iraq were found secondary metabolites; those were phenols, 
terpenoids, alkaloids, and flavonoids (Rashid, 2014).

The results showed the ethanol extract of $B$. variegata leaves contained tannins, saponins, terpenoids and alkaloids. While the infusion of $B$. variegata leaves contained tannin and alkaloid. This study was not in accordance with the previous studies because the compounds which present in the leaves of $B$. variegata were not extracted perfectly and also the differences of place where the plants grow as well as the environment such as temperature, $\mathrm{pH}$, and mineral content of the soil.

\section{Conclusion}

1. The ethanol extract and infusion of $B$. variegata leaves did not have antibacterial activity toward Streptococcus pyogenes.

2. The compounds in the ethanol extract of $B$. variegata leaves were tannins, saponins, terpenoids and alkaloids while the infusion of $B$. variegata leaves consisted of saponins and alkaloids.

\section{Suggestions}

1. Extraction method should be done the by the other methods and other solvents that can sum up the compounds which responsible toward the antibacterial activity more like soxletation, macerated by continuous stirring and done the fractionation.

2. Other bacterial species can be used to analyze the antibacterial activity of $B$. variegata.

\section{References}

Ansel, H., 1989, Pengantar Bentuk Sediaan Farmasi, 608-609, Jakarta, UI press.

Cappucino, J. G. \& Sherman, N., 2013, Manual Laboratorium Mikrobiologi, editor Miftahurrahmah, N., diterjemahkan oleh Manurung, J. \& Vindhayanti, H., 74, 104, Jakarta, Penerbit Buku Kedokteran EGC.

Depkes RI, 1979, Farmakope Indonesia Edisi Ketiga, 12, Jakarta, BPOM Depkes RI.

Dhale, D. A., 2011, Phytochemical screening and antimicrobial activity of Bauhinia variegata Linn., Journal of Ecobiotechnology, 3(9), 04-07.

Farnsworth, N.R., 1966, Review Article Biological and Phytochemical Screening of Plants, Journal Of Pharmaceutical Sciences, 55(3): 225-268.

Hartati, A. S., 2012, Dasar-dasar Mikrobiologi Kesehatan, 139, Yogyakarta, Nuha Medika.

Jawetz, E., Melnick, J. L. \& Adelberg, E. A., 1991, Mikrobiologi untuk Profesi Kesehatan, 248249, Jakarta, Penerbit buku kedokteran EGC.

Joshi, B., Lekhak, S., \& Sharma, A., 2009, Antibacterial Property of Different Medical Plant: Ocimum sanctum, Cinnamomum zeylanicum, Xanthoxylum armatum, and Origanum majorana, Kathmandu University Journal of Science, 5(1), 143-150.

Mardiastuti, H.W., Kurniawati, A., Kiranasari, A., Ikaningsih, \& Kadarsih, R., 2007, Emerging Resistance Phatogen : Situasi Terkini di Asia, Eropa, Amerika Serikat, Timur Tengah, dan Indonesia, Depertemen Mikrobiologi Fakultas Kedokteran Universitas Indonesia, 57(3), 75-79.

Mali, R., G., Mahjan, S. G., \& Mehta, A. A., 2008, Evaluation of Bauhinia variegata Linn stem bark for anthelmintic and antimicrobial properties, Journal of Natural Remidies, 8, 39 43. 
Mishra, A., Sharma, A. K., \& Kumar, S., 2013, Bauhinia Variegata Leaf Extracts Exhibit Considerable Antibacterial, Antioxidant, and Anticancer Activities, BioMed Research International.

Pratiwi, S. T., 2008, Mikrobiologi Farmasi, 188-189, Jakarta, Airlangga.

Rashid, K. I., Ahmed, S.J., \& Mahmood-Muktar, Z.F., 2014, Study the Antibacterial Activity of Bauhinia variegata Linn. plant Leaf Extracts Against Some Species of Pathogenic Bacteria, Journal of Al-Nahrain University, 17 (1), 55-559.

Syahrurachman, S., Chatim, A., Kurniawati, A., Santoso, A. U. S., Harun, B. M. H., et al, 1994, Buku Ajar Mikrobiologi Kedokteran Edisi Revisi, 112-119, Jakarta, Binarupa Aksara.

Wagner, H., \& Bladt, S., 1996, Plant Drug Analysis: A Thin Layer Chromatography Atlas, Second edition, Germany, Springer. 